\title{
What Democracy Should Compel Through Religion
}

\section{A. Duncan Yocum, Ph.D.*}

The only relationship which this topic bears to either elementary or collegiate education is that it is part of a larger study of existing factors in American life and education which tend to a truer and completer democracy. "My Democracy Questionnaire," with which some of you are familiar, is a definite and detailed summary of democratic elements in school organization, the social activities of the elementary school, its curriculum and methods of instruction. My monograph on "General Education as a Factor in Democracy" sent out to a representative group of American thinkers, is an effort to direct attention to similar elements and tendencies in the field of higher education.

What I shall say to you to-day, involves another aspect of my inquiry and propaganda-an effort to determine the extent to which each phase of social life and each great social institution have contributed, are contributing and can be made to contribute to democracy.

In a larger sense, in so far as religion is concerned, the whole program of the present session of the Association is an answer to this question. I wish, however, to ask it in more definite form and from three distinct standpoints: First, from that of the qualification of individualism or personal liberty, fundamental to a truer and completer democracy; Second, from that of the effect of the Great War upon the contributions of religion to democracy so qualified; and Third, from that of what democracy has the right to demand of religion, rather than the traditional demands of religion upon democracy in common with all other phases of human life. The motive back of all is that if democracy is not aggressively developing and moving forward in every phase of social life, it will be weakly on the defensive against communism with its demand for the surrender of all individuality, Bolshevism with its brutal leveling down and disregard for all individual rights except those of individuals belonging to a particular social class, and even Socialism with its insistence upon a greater surrender of individuality than is essential to at least the immediate common welfare, and a correction of inequalities so rapid and retrospective that it will in itself work inequalities.

Democracy is not a mere governmental form or a state of being, resulting from decrees and declarations or even international agreements for the enforcement of peace. It is a growth, a development, an attitude of mind-the product of an education which comes not only through the school and the course of human events, but through the recognized aims of each great social institution. If democracy, rather than more radical and inequitable forms of readjustment, is to be the medium for the great social, economic and political changes already

-Dr. A. Duncan Yocum is Professor of Educational Research and Practice at the University of Pennsylvania. 
under way, at least the following six qualifications of individual rights must be taught through the school and become a conscious aim of the church as well as of every other truly democtatic social institution:

I. Limitation of individual rights. Individual rights are limited by common rights and have as their safeguard every selfrestraint and self-sacrifice on the part of each individual necessary to equal rights for all, and submission by each to all the compulsion that is essential to the common welfare, but to no more than is essential.

2. Compensation for rights through service. Individual rights received through the community or the state must be paid for as fully as possible by equal or equivalent individual service.

3. A leveling up the only means to permanent equality. Both from the standpoint of the individual and the state, democratic equality demands a leveling up in place of a leveling down.

4. Self-achievement. The higher levels of democracy and equality, while open to all through legal opportunities, must be won by each individual for himself through personal effort, including all the education necessary to make it successful.

5. Equality through highest individual effort. Except in those exactions of the state which are independent of relative individual ability, equality of individual achievement, whether of rights or of service, is possible only in the sense of the highest and therefore equal individual effort.

6. Common compulsion of all essential equalities not individually self-achieved. Both in life and in education the minimum standard set up by majority rule as essential to the common welfare, in so far as it is not individually self-achieved, must be compelled of all.

That our democracy is as yet too individualistic even in the fields where religion and morality are most concerned, is shown by the opposition of certain distinguished gentlemen to the Prohibition Amendment on the ground that the founders of the Constitution never contemplated state control of individual morals or personal habits. Would there not be less talk of a "beer strike", if to the teaching of temperance hygiene were added training in the necessity for surrendering even what is to a particular individual a harmless personal right for the sake of the common welfare?

In a Democracy Even Religious Liberty Has Its Limits.

(I) Has democracy limited religion enough to protect itself? (2) If what Germany has contemptuously called the "older moralities" are essential to the well-being and continued existence of democracy, should not religious cults be prohibited by national law from antagonizing them? (3) If democracy must be safeguarded through the morality which it is the peculiar function of the Church not only to teach, but to religiously motivate, is it not still more essential that the 
Church should be compelled by the State to avoid all undemocracy in its teachings and activities? (4) If it cannot preach sedition and gain immunity by pleading religious motive, should it be undemocratic in its organization, in its fundamental teachings, and in its fashionable churches for the rich, and its chapels for the poor? These undemocracies often in their sum total more undermining to religion and democracy than open sedition itself, yet too indefinite to be forbidden by law, have already become a serious concern to a religious leadership which is courageously facing the gigantic problems which come with social readjustment.

There Is No Limit to the Right of the Church to Seek Political Remedy for Human Inequalities and Wrongs. In general it is not too much to say that through public sentiment rather than by law, the Church has been too much limited in its attempts at political activity. The public rightly resents and fears any effort on the part of a particular church or denomination to gain political power and influence to be used in its own behalf or for the political advancement of its individual members. It is in this sense and only in this sense that democracy has drawn the line between church and state. (5) Is sharp distinction possible between a particular church's effort to gain political favor and influence to be used in its own behalf or for the political advancement of its individual members, and a united effort of churches and religious bodies to exert political pressure favorable to obviously moral, social and economic reforms? One of the most significant effects of the war upon church activities is the recent action of the Administrative Committee of the National Catholic War Council in announcing a broad social program for the Church dealing with every form of betterment, from legislation against child-labor to insurance against unemployment, and the continuance of heavy taxes on large incomes and excess profits. (6) Do not the future safety and service of democracy depend upon the cooperation of all denominations in such a movement? (7) Do any other denominational programs such, for instance, as the Methodist Centennary Fund, involve propaganda for economic and social reform?

Does Religious Liberty Give the Individual the Right Not to Be Religious at All? After all, we as Americans are as yet so individualistic in our democracy that we are less shocked by the thought of limitation of the liberty of the Church, than of any infringement of the right of the individual to worship God as he pleases. But; (8) If religion is fundamental to democracy, does the right to worship God as one pleases carry with it the right not to worship $\mathrm{Him}$ at all, and to prevent our children from having, under public control, moral and religious training in what is common to all creeds, and under church control what is peculiar to some selected creed? Furthermore; (9) If religion itself directly furthers democracy through such teachings as self-sacrifice for others-especially for the weak, and responsibility for the welfare of all peoples, and indirectly furthers it through more 
strongly motivating morality, is it democratic that vast numbers of citizens are exempt from contributions to the support of public worship and religious instruction, or that such contributions as are made are not in proportion to individual ability? (10) From the same point of view, is it democratic that members of churches which insist upon sectarian training for their children should be doubly taxed? Bolshevism's answers to these questions is no church or religion at all; Communism's, either church attendance and support for all or for none; Socialism's would vary with the social group. Our present individualistic democracy's reply, even in the face of a deadly menace to which it is partly awake, will probably be that a compulsion, perhaps forever impossible through law, can be and must be exercised through education. (II) Can democracy safely put its trust in the fundamental religion which is in almost every individual, and in a growing realization on the part of the churches of their responsibility to democracy, or must the State attempt some compulsion of its own? (12) Should not the Church include in its own teachings and demand as a part of the required work in every school where attendance of children is compelled by the State: the duty of every individual to adhere to, to attend upon and to support some form of public worship which he selects for himself, and to have his children trained in the minimum of religion and morality essential to democracy? (13) Should not all churches conspicuously and continually impress upon their membership, the debt owed to democracy in return for religious liberty, and the various ways in which religion can pay it? The Service Which the Church Owes to Democracy in Com-
pensation for Religious Liberty.

As surely as there are few individual rights which do not demand in return compensating service, the right to religious liberty which the Church has received through democracy demands in return every form of service which the Church can render democracy. (14) Cannot and should not the Church give moral and religious motivation to the qualifications of individual liberty which most sharply distinguish democracy from Bolshevism: the limitation of individual rights, the democracy of the higher levels, democracy through self-achievement, equality through highest effort, and the compulsion impossible to the State, of the minimum essentials of democracy in all aspects where the Church can and should control? The teaching of morality and religion in general to those citizens who are willing to be taught, performs but in part the fundamental service which the Church owes to democracy. Both religion and morality can be undemocratic.

The Church Owes to Democracy the Emphasis of Every Democratic Element in Morality and Religion. With the motive of compensating service every churchman given the right to worship God as he pleases, should permanently associate at least democracy through religious teaching, through religious service, and through religious meetings and 
social activities; (I5) Does not the Church owe to democracy in compensation for religious liberty the emphasis as democratic, of those elements in morality and religion that tend to equality-for example, honesty and truth-telling as giving men an equal chance in business and social affairs, or concern that other individuals and peoples shall have opportunities equal to one's own? Most moralities when analyzed have as their aim some sort of equality, but they are rarely taught in their democratic aspects. Religion has definitely contributed the democratic antithesis of the false materialism and Nietszhianism which have been the intellectual sanctions of Prussianism, and the means to emotionalizing and idealizing it through modern German literature.

Compensation for religious liberty should suggest to every individual democracy through service in the three-fold sense of cooperation of the churches in social reconstruction, of compulsory individual participation in some form of social service, and of recognition of self-sacrificing service as the highest evidence of religious faith.

Importance of Continuing and Strengthening the Three-fold Emphasis Which the War Has Placed Upon Service. (16) Is the chief religious change which has at least temporarily been brought about by the war, a three-fold re-emphasis of service: First, cooperation of denominations and local churches in social service; Second, a more general individual participation in it; and Third, at least the vague consciousness on the part of all serving in the Great War, that service for others has a fundamental religious significance? (I7) Has participation in various forms of war service been general enough for the churches to insist upon some selected form of social service on the part of each individual as a condition to continuance in church membership? (18) Was Donald Hankey right in insisting that there is a vague but general belief in the bigness of self-sacrifice and service for others, which constitutes "the religion of the inarticulate"? (19) Is Judge Lindsey right in his belief that the more or less hostile attitude of some of the cross-seas men toward the Y. M. C. A. is in part due to the emphasis by certain workers of the abandonment of more venial sins for the sake of personal salvation, in appealing to men who were making the supreme sacrifice for others? (20) In any event, will it not strengthen the more selfish appeal to the desire for personal salvation, if men are first made conscious of the religion which they possess or admire in the form of the supremer sacrifices, and the lesser virtues are demanded of them on the ground that their lack interferes with the general welfare and with otherwise efficient individual service? I do not mean that intemperance and other venial sins should be any less earnestly fought, nor that personal salvation and well-being should not be appealed to as powerful incentives to virtue. Nor do I urge that self-sacrifice for others can be as continuing a motive in ordinary life as in times of individual and national emergency. My viewpoint is, rather, First-that wherever and whenever self-sacrifice for others is found in good men or otherwise evil men, it should be seized upon as 
the greatest of all good and used as the most powerful of all means to the development of other goods which they lack; and, Second-that it should be patiently and lovingly looked for in otherwise evil lives and environments, where it may exist as a virtue as undreamed of by its possessor as by those who rightly condemn the wrong which surrounds it.

Even Charity Should Tend to Develop in its Recipients the Personal Dignity Which Seeks to Give in Return. Democratic in itself, the realization of the necessity for compenating service to our fellow men for what we have received from God, may carry over or "transfer" to the civic duties which we owe in return for the rights which democracy gives us. (2I) Should not charity workers, therefore, be made conscious of the service to democracy in awakening in the recipients of charity the wish to give in return some compensating service to the donor or others? The service lies not only in the resulting personal dignity, but in its probable transfer to civic life in general, where increasing governmental control of public utilities will become paternal and imperial if the individual citizen does not consciously give in return for everything which he receives.

All Social Activities of the Church Should be Democratic. The Church owes to democracy compensating service not only through the emphasis of democracy in its teaching of morals and religion, and through the three-fold emphasis of service just discussed, but by contributing to democracy through all of its social activities. Common religious feeling and belief and the common enjoyment of religious exercises are in themselves a social bond. The fellowship of social service equally shared is a yet surer means to community feeling. But the intercourse which is wholly religious in its purpose may fail to contribute to a fully democratic intercourse which in its larger sense is based upon common correctness of language and of manners, common ability in a variety of games and amusements, common tastes and appreciations, and the common general ideas and associations essential to ordinarily intelligent conversation.

Church Membership Should Raise Every Individual to a Higher Soctal Level.

Social stability, the balance necessary to the continued existence of governmental forms and social institutions, is dependent upon a leveling up-a democracy which leads to the equality of the higher levels. Unlike the French Revolution and Bolshevism, permanent democracy means a struggle toward higher levels rather than a pulling down to the dead level of ordinary attainment. Religion more than any other social institution has for its chief function a leveling up. The gradual raising of the moral and religious ideals of a race or a nation is the most certain measure of the progress of its civilization and its development of true democracy. But in a more specific sense the Church should make large contribution to the progress of individuals and of social and 
economic groups toward the more stable social intercourse which comes from a leveling up.

(22) If personal adornment and the wearing of expensive dress are the outward signs of success in the struggle toward a higher level of living, is not uniform dress for all church members or the putting aside "gold and costly apparel," a social leveling down? (23) Will not the same equality be attained from a leveling $u p$, if both in their public worship and social activities the churches teach good taste in dress and discourage ostentatious display? (24) Is not Billy Sundayism a social leveling down, justifiable only through its moral and sometimes spiritual uplift for men who have suffered through the Church's neglect of activities which represent a social as well as religious leveling up? (25) Would not this social leveling up find its inspiration on the side of good manners, in a more earnest and effective teaching of "the seeking not of one's own," "backbiting not with the tongue," "thinking no evil," and "in honor preferring one another"? (26) Should not the Church as it becomes increasingly institutional, definitely seek, like the socialized High School, to promote through its social activities and organizations, the correct language and manners which insure unembarrassed entrance into any social group?

The Church Should Become a Positive Factor in Elevating the Standards of Common Amusements. A far greater opportunity for contribution by' the Church to social leveling up lies in the realm of games and amusements. Men are not wholly brethren in religion or democracy until they play together. Here the attitude of the Protestant Church at least, has been largely negative. (27) Would not certain of the churches exercise more of a leveling up influence on common games and amusements including card-playing and dancing, if in place of attempting to prohibit them, they would teach the distinction between proper and immoral forms of the same kind of play, and stand behind the effort of polite society itself to maintain standards of good taste? (28) With Sunday as the chief leisure time for the masses, should not certain religious workers substitute for their negative attitude toward all Sunday amusements, an effort to adapt church service to a greater variety of social needs, a campaign to secure from every individual attendance upon at least some one form of religious service each Sunday, the endorsement and so far as practicable the provision of wholesome Sunday amusements of a sort which either call for personal participation or demand a minimum amount of work from others, and cooperation with labor organizations in insuring the opportunity for Sunday rest and worship to the greatest possible number of individuals?

If some churches and individuals cannot conscientiously transform their negative attitude toward the most natural and human amusements, to an effort to ensure right standards and to avoid extraneous abuses, all can certainly unite in a positive movement to create and to elevate common tastes and appreciations.

The Church Should Further a Leveling Up in Common Tastes and 
Appreciations. A common appreciation of the beautiful in the greatest practicable variety of forms is obviously one of the most fundamental elements in the democracy of a higher level.

(29) Assuming that religious rag-time and mediocre hymns may be religiously necessary, should not the music of church organs, orchestras and choirs be more consciously selected with a view to the common development of a varied appreciation for what is finest in music, and, to that end, be definitely associated with the names of composition and composer, form of composition, and the country and period in which it was produced? (30) Should not the books in the Sunday school library be selected and in part furnished through the cooperation of the officials of school and public libraries, not only with a view to moral and religious appeal, but to their playing some part in creating a common appreciation for a variety of standard books and writers? (3I) To what extent can the Church follow the lead of the socialized school in organizing a variety of clubs and societies for individuals having or wishing to have common interests in the fine arts?

So far as is practicable, the Church must see that the moral and religious betterment fundamental for all social uplift, is accompanied by every aesthetic concommitant essential to equal and democratic social intercourse.

Will Fitness for Service Prove an Effective Incentive to SelfAchievement and Equality Through Highest Effort?

Although no social institution has done more than the Church to develop the democracy which lies in self-achievement and the equality which comes through highest individual effort, most men rest satisfied with the minimum moral and religious standards demanded by society. They are ethically unequal only because they do not strive with all their might. (32) May not the three-fold emphasis given by the war to service as the expression of religious life be so utilized as to bring about a more normal sizing up of individual availability for particular - forms of social duty, together with the growing individual consciousness of personal abilities and limitations, and a strong stimulus to develop one's highest efficiencies and to remove all that stands in the way of the service for which one would otherwise be fit?

Wherever Self-Achievement Fails, the Minimum of Religion Essential to Democracy Should Be Compelled.

The most individualistic institution in democracy is the Protestant Church. Judaism compels certain ceremonials and the Old Testament form of education. Catholicism compels creed, church attendance and maintenance, accounting for personal conduct and, wherever practicable, a religious and sectarian training for young children. Protestantism compels nothing.

Protestantism's Responsibility for a Religion No Longer Compelled by the State. (33) Have not those of us who are Protestants assumed 
a peculiar responsibility to the State for the maintenance of religion, when we insist that the State shall no longer compel it? What sanction or compulsion have we substituted? The Great War has probably done much io strengthen religious feeling and to universalize the sense of service, but outside of compelling men while in the Army or Navy to attend religious exercises, it has added no new compulsion from the standpoint of the State. All responsibility for the religion and morality basic for democracy is still left to the Church. If the Church fails to compel the religious minimum essential to the national safety, the continued existence of democracy is imperiled.

The Minimum Compulsion Essential to Democracy. The efficiency of a compulsion to which men voluntarily submit depends very largely upon what is compelled. Creed cannot be compelled by churches which insist upon freedom of belief. (34) Will the minimum of religious compulsion essential to democracy be reached, if the Church in addition to its appeal for the self-achievement of all religious good, compels of every member participation in a selected form of social service and such attendance upon church or various forms of meetings as is necessary to ensure efficiency to the service; demands and exacts financial support of every member to an amount for which he is assessed by a duly elected committee in proportion to his ability to pay; and insists both upon the regular attendance of the children of all members upon some adequate form of sectarian religious instruction and their skilled and well organized training in all public schools in the morality and religion fundamental to all creeds, with special emphasis of the bearing of morality and religion upon democracy?

Favorable Conditions to Efficient Religious Compulsion. If the Church is more discriminating, adaptive and compelling in its demands, the individual will take his religious responsibility more seriously. (35) Is not compusion more likely to be freely accepted: First, if discrimination is made between necessary and minimum exaction and voluntary performance, between greater and lesser sins and virtues, and between essential or undeniable truths and what must be left to individual belief. and judgment? Second, if general worship be made far more limited in its amount, and dignified and impressive in its form? Third, If religious exercises and social service are sufficiently varied to meet the needs of every individual, and most exercises or services definitely planned to call for the attendance and support of selected and specified groups?

Religious Training in Place of Being Merely Informational and Catechetical Must Come to Include Everything Which Can Control Experience. (36) Has not the time come when public opinion can be led by a united Church to make some form of effective religious instruction, including training in a selected creed, compulsory for all children in the State? (37) Must not the religious training of children be as widely different from the old informational and catechetical instruction which Mathew Arnold condemned, as the organized service 
of the churches must differ from the traditional expounding of dogma? (38) Must it not strongly enough emotionalize, religious interest, realizations, tastes and appreciations, ideas and standards, and motives and incentives, to make them controlling; associate them in the minds of children with a wealth of vocabulary, including both the multitude of words necessary to make religion intelligent and discriminating and general terms with the suggestive associations necessary to openmindedness, toleration, balanced judgment, and ability to do religious thinking; insure the habits, skills, modes of thinking and procedures, essential to right conduct and efficient service; and, perhaps above all, be so organized as to create the conditions most favorable to the general application and transfer of useful feelings, ideas and habits into every kind of activity and every field of experience?

Purpose of the Paper.

I am sure that most of this may appear visionary and to some of you visionary without being idealistic. But, what has seemed visionary in the past or too human to be idealistic, becomes intensely practical and compelling in the face of a Prussianism which scoffs at morality and a Bolshevism menacing both religion and democracy. As a mere expression of personal opinion it is quite futile. It has not been written, however, to give a personal viewpoint, but as a basis for determining current attitudes and tendencies in religious leadership under the stress of reconstruction and threatened revolution. It will be sent to a selected group of religious thinkers and officials, and the resulting replies will be analyzed and summarized with a view to determining whether religion has been modified by the war, to what extent the Church recognizes the fact that personal and institutional religious liberties must be limited by what is necessary to the common welfare, and what practical forms of compensating service it is willing to perform for democracy in return for religious liberty. One thing is sure: the education both of church and of school must either be prophetic and anticipatory, or become subject to the whims and the compulsions of current events which it will fail to shape and to control. 